\title{
O papel do mediador em Michèle Petit: contribuições à discussão sobre práticas de leitura na constituição pessoal e profissional do sujeito
}

\author{
Ana Carolina Porto Garcia*, Cláudia B. de C. Nascimento Ometto.
}

\section{Resumo}

O objetivo central da presente Iniciação Científica é identificar, nas obras (editadas em português) de Michèle Petit, as funções e contribuições da leitura na constituição dos sujeitos e, em especial, buscar relacionar as experiências de leitura ao desenvolvimento pessoal e profissional de professores, extraindo lições para mediação das/nas práticas de leitura na formação dos docentes e discentes. Os estudos de Petit tratam da temática da leitura, especificamente em países em desenvolvimento, tendo como objeto de estudo o papel da mediação e das bibliotecas públicas na luta contra os processos de exclusão e segregação de jovens de bairros marginalizados. Embora sua obra não trate especificamente da formação de professores e das contribuições da leitura em bibliotecas escolares, suas pesquisas podem contribuir para que formadores de leitores - tanto na escola básica quanto no ensino universitário - extraiam lições importantes para a mediação de distintas práticas leitoras nesses espaços privilegiados de formação dos sujeitos.

Palavras-chave: Mediação, biblioteca escolar, formação de professores.

\section{Introdução}

A presente Iniciação Científica parte de questionamentos sobre as funções e contribuições da leitura na constituição dos sujeitos a fim de relacioná-las ao desenvolvimento pessoal e profissional de professores. Analisa-se as obras da antropóloga francesa Michèle Petit (1946-) a partir da leitura do livro "Os Jovens e a Leitura" (2008), que anuncia seu objetivo já no título, e em suas páginas confirma a importância da leitura na constituição pessoal do sujeito. É uma pesquisa, de natureza bibliográfica.

Embora as obras de Petit não tratem especificamente das contribuições da leitura e da literatura para a formação de professores seus textos podem inspirar modos de mediação e políticas de formação aos formadores de professores para 0 planejamento $e$ encaminhamento de práticas que incorporem a leitura e a literatura como experiências de desenvolvimento pessoal e profissional em um encontro dialético/dialógico das experiências do lido com o vivido.

\section{Resultados e Discussão}

Os eixos definidos que nortearam a pesquisa buscaram tratar sobre, Experiências de Leitura, e suas categorias, "A experiência da narrativa - como precursora da literatura" (1.1); "A leitura da literatura como experiência simbólica" (1.2); "A leitura da literatura como experiência de imaginação/criação" (1.3); "A experiência da leitura da literatura no universo da indústria cultural" (1.4). Seguindo para o Papel do Mediador nessa constituição do sujeito leitor com os eixos "O conceito de mediação simbólica" (2.1); "Os mediadores fora da escola (familiares, assistente social etc.)" (2.2); "Os professores como mediadores" (2.3); "A mediação dos bibliotecários" (2.4); e, por último, os Espaços de Leitura com as categorias "A leitura na sala de aula" (3.1); "A leitura na biblioteca" (3.2), finalizando com "A leitura em outros espaços" (3.3).

\section{Conclusões}

Os resultados evidenciam que a leitura da literatura possui um caráter formativo, uma vez que o sentido ao que se lê é polissêmico - inversamente proporcional à leitura de textos científicos - e atribuído pelo leitor, que compreende e se articula ao texto, dele apropriando-se a partir das palavras que já lhe constituem. Nesse processo, fundamental é o papel do mediador que possibilita aos sujeitos o contato com os textos em seus mais diversos suportes e locais nos quais se pratica a leitura. Ler, nesse sentido, é uma atividade constitutiva do sujeito, pois leva-o para além de si mesmo e o retorna a seu lugar, contudo, quem retorna, já não se configura da mesma forma, tendo expandido seu horizonte, suas possibilidades, sem sequer sair do lugar em que se encontra fisicamente. O papel mediador do mais experiente é fundamentalmente importante na constituição do outro. $E$ isso não é diferente para alunos e professores, uma vez que a profissionalidade constitui-se inexoravelmente amalgamada a constituição da pessoalidade.

\section{Agradecimentos}

Agradeço à minha família, à minha orientadora, à Faculdade de Educação da Unicamp e o SAE - UNICAMP que me deram o suporte necessário à realização desta pesquisa.

PETIT, Michèle. Os jovens e a leitura: uma nova perspectiva. Tradução de Celina Olga de Souza. São Paulo: 34, 2008.

PETIT, Michéle. A arte de ler ou como resistir à adversidade. Tradução de Arthur Bueno e Camila Boldrini. São Paulo: 34, 2009.;

PETIT, Michéle. Leituras: do espaço íntimo ao espaço público. Tradução de Celina Olga de Souza. São Paulo: 34, 2013. 